\title{
ПРОБЛЕМИ НОРМАТИВНО-ПРАВОВОГО РЕГУЛЮВАННЯ ДЕРЖАВНОГО ФІНАНСОВОГО КОНТРОЛЮ В УКРАЇНІ ТА НАПРЯМИ ЙОГО ВДОСКОНАЛЕННЯ
}

Прасюк В. М.

Стаття присвячена аналізу проблем нормативно-правового регулювання державного фінансового контролю в Україні та пошуку напрямів його вдосконалення. Зауважено, що вирішення актуальних проблем нормативно-правового регулювання державного фінансового контролю в умовах постійних змін національного законодавства неможливо без їх наукового аналізу. Проаналізовано позиції науковців щодо виокремлення проблем формування й функціонування системи державного фінансового контролю в Україні. Звернуто увагу на стан законодавства, яке регулює відповідне питання. Так, акцентовано на тому, що спеціальне законодавство про державний фінансовий контроль формувалося на початку 90-х років минулого століття, на сьогодні воно виглядає досить застарілим, не відповідає сучасності, вимагає оновлення та модернізації. Положення базового Закону України «Про основні засади здійснення державного фінансового контролю в Україні» потребують докорінного вдосконалення, оскільки зберігають низку проблем, які в статті виокремлені й проаналізовані.

Ключові слова: контроль, державний контроль, державний фінансовий контроль, публічні фінанси, фінансові ресурси, нормативно-правове регулювання.

Статья посвящена анализу проблем нормативно-правового регулирования государственного финансового контроля в Украине и поиска направлений его совершенствования. Отмечено, что решение актуальных проблем нормативно-правового регулирования государственного финансового контроля в условиях постоянных измене ний национального законодательства невозможно без их научного анализа. Проанализированы позиции ученых относительно выделения проблем формирования и функционирования системы государственного финансового контроля в Украине. Обращено внимание на состояние законодательства, регулирующего соответствующий вопрос. Так, акцентировано на том, что специальное законодательство о государственном финансовом контроле формировалось в начале 90-х годов прошлого века, сегодня оно выглядит довольно устаревшим, не соответствует современности, требует обновления и модернизации. Положение базового Закона Украины «Об основных принципах осуществления государственного финансового контроля в Украине» требуют коренного усовершенствования, поскольку сохраняют ряд проблем, которые в статье выделены и проанализированы.

Ключевые слова: контроль, государственный контроль, государственный финансовый контроль, публичные финансы, финансовые ресурсы, нормативно-правовое регулирование.

The article identified the problem of legal regulation that occurred in Ukraine and suggested its introduction. He noted that the urgency of the current problem of regulatory and legal regulation, which occurred in different regions of the legisla-

Прасюк В. М., 2019 tion, is impossible without their scientific activity. The positions of researchers on the identification of the problem of development and functioning of systems that worked in Ukraine are analyzed. Notice the state of the law governing the answers to the questions. Yes, it is emphasized to date that the legislation on the state level of control, which is formed in the process of the 90s of the past life, has been reported, and today it remains authentic, not modern, requiring updating and modernization. Improvements to the basic Law of Ukraine "On Fundamental Principles exist in different regions of Ukraine" need to be radically implemented and a number of problems need to be identified and analyzed.

It is proved that the existing national system of regulatory and legal regulation uses the rest, which remains behind the number of "elaborated" laws and by-laws, which are undoubtedly significant problems, but there may be law enforcement that creates gaps in any case, in particular, and at the same time. introduces a real imbalance in legislative legislation. The implementation of the process of elimination of problem-legal regulation, which is performed in two priority directions (general-special), is proposed. It is justified that a comprehensive reform of the legislative framework was used to achieve this, when everything was used and it was achieved, and it was achieved, and it was very difficult, but it was difficult, and it made it possible to reach public administration. about adequate obligatory state essential resources, and, as a result, positive to learn about something truly developed as a whole.

Key words: control, state control, state control control, public indicators, basic resources, regulatory regulation.

Постановка проблеми та їі актуальність. У сучасних реаліях наявної ситуації в державній економіці, зростання впливу світових фінансових чинників, глобалізації відповідних процесів і міжнародної конкуренції система державного фінансового контролю в Україні $\epsilon$ досить розвинутою, але, незважаючи на це, відповідний контроль характеризується наявністю певних недоліків у фінансовій практиці, нецільовим і неефективним використанням бюджетних коштів, відсутністю належного законодавчого підґрунтя контрольно-фінансової діяльності, нормативного визначення змісту державного фінансового контролю, його мети, вимог до проведення, недосконалістю запроваджених форм і методів контролю, що негативно впливає на стан державних фінансових ресурсів, уповільнює розвиток функції публічного адміністрування й, безумовно, потребує вдосконалення.

Розбудова дієвої системи державного фінансового контролю, пошук шляхів реформування різноманітних аспектів організації та здійснення зазначеного контролю, комплексне розв'язання наявних проблем у відповідній сфері за умови вжиття на загальнодержавному рівні заходів щодо усунення недоліків у практичній діяльності суб'єктів державного фінансового контролю 
і спрямованих на оптимізацію та підвищення ефективності державного фінансового контролю, активізація його ролі в нинішніх публічних фінансових правовідносинах $\epsilon$ актуальним питанням. Саме тому вкрай необхідним $\epsilon$ дослідження стану державного фінансового контролю в Україні в контексті виявлення проблем його нормативно-правового регулювання та визначення пропозицій щодо напрямів його вдосконалення.

Аналіз останніх досліджень і публікацій. Вирішення актуальних проблем нормативно-правового регулювання державного фінансового контролю в умовах постійних змін національного законодавства неможливо без їх наукового аналізу. Дослідженню різних аспектів формування та функціонування системи державного фінансового контролю в Україні, зокрема ii проблемам, приділено увагу багатьма провідними науковцями. Так, Г.М. Азаренкова шляхом порівняльного аналізу здійснила систематизацію поглядів учених щодо виокремлення недоліків державного фінансового контролю, серед яких виділяє проблеми законодавчого характеру, відсутність розмежування повноважень суб'єктів державного фінансового контролю, недосконалість механізмів відповідальності за вчинення правопорушень у сфері державних фінансів [1, с. 282]. Т.Б. Жураковський наполягає на необхідності реформування системи державного фінансового контролю шляхом упровадження таких заходів: удосконалення законодавчої бази, нормативно-правових актів, інструктивних і методичних документів; створення й відпрацювання механізму координації роботи контрольних служб; застосування відрядно-преміальної системи матеріально-технічного забезпечення контрольних органів; вивчення й використання іноземного досвіду щодо проведення державного фінансового контролю [2]. Н.І. Шевченко, В.О. Куліченко на основі проведеного оцінювання сучасного стану державного фінансового контролю в Україні виокремлюють проблеми його організації та здійснення, а також пропонують напрями реформування системи державного фінансового контролю. Найважливішою проблемою називають методологічну, пов'язану з недостатнім з'ясуванням природи внутрішнього й зовнішнього фінансового контролю [3]. Т.О. Пожар у результаті дослідження функціонування фінансово-бюджетного механізму державного фінансового контролю виявлено комплекс проблем правового, організаційного, кадрового, методологічного характеру та визначено основні напрями їх подолання [4, с. 63]. Є.М. Романів, Д.В. Долбнєва акцентують увагу на проблемах державного фінансового контролю щодо правового, інформаційного, організаційного, комунікативного, методологічного та кадрового забезпечення, що негативно впливає на розвиток фінансово-бюджетних відносин, пропонують шляхи вдосконалення відповідного контролю на державному та місцевому рівнях [5, с. 38]. К.Є. Дубовик, В.Г. Горник, В.В. Шпачук, С.О. Кравченко, ураховуючи аналіз сучасної організаційної системи державного фінансового контролю в Україні на центральному рівні, наголошують на тому, що вдосконалення потребують усі елементи цієї системи: суб'єкти, об'єкти (як фінансова система загалом, так і конкретні об'єкти кожного контролюючого органу) та контрольні дії [6, с. 343]. О.М. Есмановим на основі узагальнення проблем функціонування державного фінансового контролю на різних рівнях визначено перспективи його розвитку з урахуванням затверджених міжнародних принципів організації фінансового контролю [7]. Т.О. Голоядова висвітлює нормативні проблеми понятійного апарату у сфері функціонування державного фінансового контролю та наголошує на потребі їх удосконалення та систематизації з позицій світової практики [8, с. 71]. Ю.О. Ровинський уважає стратегічними напрямами модернізації системи правового забезпечення державного фінансового контролю такі: формування правової бази контролю, яка відповідає політичному устрою й економічному розвитку країни; створення на всій території країни єдиного поля фінансового контролю за наявності вираженої контрольної вертикалі; утворення стійкого кваліфікованого кадрового потенціалу органів фінансового контролю [9, с. 58]. Д.В. Молчанов на підставі зарубіжного досвіду адміністративно-правового регулювання державного фінансового контролю характеризує його стан в Україні, виділяє позитивні характеристики для можливої подальшої адаптації до сучасних умов [10]. Б.І. Сюркало до основних напрямів розвитку вітчизняної системи державного фінансового контролю зараховує прийняття Кодексу державного фінансового контролю України, який, на його думку, повинен стати системоутворювальним документом стосовно визначення суб'єктів державного фінансового контролю, їх класифікацією залежно від компетенції стосовно об'єктів контролю [11]. Проте із цим твердженням не можна погодитися, адже в разі прийняття такого кодифікованого акта він не усуне наявних проблем у системі державного фінансового контролю, а, навпаки, їх ускладнить, оскільки основними недоліками нормотворчості у сфері державного фінансового контролю $€$ їх велика кількість (причому як законів, так і підзаконних нормативно-правових актів), безліч змін і доповнень до вже прийнятих нормативних актів, зовнішні й внутрішні суперечності, неузгодженості їх положень. До того ж у наявності $€$ чинний спеціальний Закон України «Про основні засади здійснення державного фінансового контролю в Україні» від 26.01.1993, який містить основні засади щодо організації та здійснення державного фінансового контролю. Однак варто зауважити, що спеціальне законодавство про державний фінансовий контроль формувалося на початку 90-х років минулого століття, сьогодні воно виглядає досить застарілим, не відповідає сучасності, вимагає оновлення та модернізації. Так, положення базового Закону України «Про основні засади здійснення державного фінансового контролю в Україні» від 26.01.1993 [12] потребують докорінного вдосконалення, оскільки зберігають низку серйозних проблем, серед яких варто виділити, зокрема, такі:

- відсутність офіційного закріплення поняття «державний фінансовий контроль» із класифікаційним поділом на «зовнішній» $\mathbf{i}$ «внутрішній»;

- відсутність закріплення принципів державного фінансового контролю;

- відсутність єдиних стандартів державного фінансового контролю;

- відсутність визначення об'єкта та предмета державного фінансового контролю та їх структурних елементів;

- відсутність дефініції суб'єкта державного фінансового контролю; 
- відсутність єдиного трактування видів, форм, методів і засобів державного фінансового контролю;

- відсутність визначення змісту, мети державного фінансового контролю;

- відсутність визначення організаційної структури основних органів, які здійснюють державний фінансовий контроль, і розмежування їхніх прав, обов'язків, відповідальності.

Мета статті - проаналізувати проблеми нормативно-правового регулювання державного фінансового контролю в Україні та пошук напрямів його вдосконалення.

Виклад основного матеріалу. Норми інших нормативно-правових актів щодо організації державного фінансового контролю теж не врегульовують відповідні питання, наприклад, Бюджетний кодекс України закріплює контрольні повноваження органів державного фінансового контролю, однак суб'єкти, об'єкти та предмет бюджетного контролю не чітко визначено, не розкрито порядок проведення контрольних заходів суб'єктами контролю. Така безсистемність у правовому полі певною мірою призводить до розбалансованості в системі органів державного фінансового контролю.

Як уже зазначалося, чинна національна система нормативно-правового регулювання державного фінансового контролю налічує величезну кількість «розпорошених» законів і підзаконних нормативно-правових актів, що, безумовно, $\epsilon$ істотною проблемою, оскільки це ускладнює процеси правозастосування, формує прогалини в діяльності органів державного фінансового контролю, а також уносить значний дисбаланс у фінансове законодавство. Це зумовлено тим, що державний фінансовий контроль реалізується багатьма державними органами, які використовують різні методи та порядок здійснення контролю тощо. Але головна проблема у відповідній сфері полягає у відсутності саме досконалої законодавчої бази, тобто єдиного спеціального базового закону, який би чітко закріплював правові засади державного фінансового контролю. Отже, процес удосконалення проблем нормативно-правового регулювання державного фінансового контролю доцільно розглядати у двох пріоритетних напрямах:

по-перше, спеціального, що передбачає формування єдиних концептуальних засад організації та здійснення державного фінансового контролю щодо визначення складників механізму державного фінансового контролю, які не закріплено в чинному законі, тобто внесення відповідних змін до законодавства з акцентуванням уваги на вдосконаленні базових засад організації та здійснення державного фінансового контролю (нині чинного Закону України «Про основні засади здійснення державного фінансового контролю в Україні» від 26.01.1993), а саме:

- визначення понятійного апарату, зокрема норм-дефініцій, які б розкривали їх юридичну сутність і забезпечували можливість їх послідовного застосування (державний фінансовий контроль, предмет, об'єкт, суб'єкт державного фінансового контролю);

- визначення основних принципів функціонування державного фінансового контролю;

- створення й запровадження єдиних стандартів державного фінансового контролю;

- розмежування видів, форм і методів державного фінансового контролю;
- розмежування державного фінансового контролю на зовнішній і внутрішній контроль;

- оптимізація повноважень органів державного фінансового контролю (з метою недопущення дублювання з повноваженнями інших контролюючих органів) шляхом їх чіткої регламентації згідно з методами проведення контролю;

по-друге, загального, тобто гармонізації правового поля процесуальної частини базового закону у сфері державного фінансового контролю, а саме доповнення його нормами, які закріплювали б єдині чіткі, прозорі правила, порядок здійснення державного фінансового контролю органами різних гілок влади, механізм взаємодії ф обмін інформацією між ними.

Отже, комплексне реформування законодавчої бази системи державного фінансового контролю зазначених напрямів шляхом реалізації наведених вище заходів сприятиме не лише ефективній організації та здійсненню відповідного контролю, а також підвищить його дієвість, рівень фінансової дисципліни, довіру до органів публічного адміністрування з приводу відповідального використання державних фінансових ресурсів, як наслідок, позитивно позначиться на фінансовому розвитку держави загалом.

Перспективи розвитку адміністративно-правового регулювання державного фінансового контролю в Україні варто також розкривати в контексті аналізу проектів законодавчих актів відповідно до принципу правової визначеності й основних засад нормотворення, передбачених в актах міжнародного та національного законодавства. Так, наприклад, можна проаналізувати проектну роботу, яка проводилася ще досить недавно, адже з метою забезпечення належного правового регулювання в зазначеній сфері Держаудитслужбою розроблено й у встановленому порядку направлено до Верховної Ради України Проект Закону України «Про основні засади діяльності органів державного фінансового контролю» від 14.09.2018 № 9086 [13], який так і не прийнято згодом.

Згідно з пояснювальною запискою, метою прийняття Проекту Закону України «Про основні засади діяльності органів державного фінансового контролю» від 14.09.2018 № $9086 \epsilon$ вибудова сучасного та ефективного законодавства у сфері державного фінансового контролю. При цьому необхідність розроблення Законопроекту зумовлена, зокрема, Стратегією реформування системи управління державними фінансами на 20172020 роки, схваленою Розпорядженням Кабінету Міністрів України від 08.02.2017 [14], яка серед складників реформування системи управління державними фінансами визначає підвищення ефективності державного фінансового контролю шляхом посилення інституційної спроможності Держаудитслужби щодо проведення державних фінансових аудитів (спеціалізованих аудитів) і підвищення ефективності фінансового інспектування, і Стратегією сталого розвитку «Україна - 2020», схваленою Указом Президента України від 12.01.2015 [15], яка за вектором розвитку держави передбачає реалізацію, зокрема, реформи державного фінансового контролю та бюджетних відносин, проте зазначеними стратегіями не передбачено розроблення нової редакції закону щодо діяльності органів державного фінансового контролю. Разом із тим, відповідно до Концепції реалізації державної політики у сфері реформування сис- 
теми державного фінансового контролю до 2020 року, схваленою Розпорядженням Кабінету Міністрів України від 10.05.2018 [16], одним зі способів розв'язання проблем реформування системи державного фінансового контролю визначено завдання щодо розбудови уніфікованої нормативно-методологічної бази і стандартизації державного фінансового контролю, зокрема вдосконалення та посилення інституційної основи наявних видів державного фінансового аудиту, що проводить Держаудитслужба, і впровадження в діяльність нових видів і форм аудиту шляхом розроблення Держаудитслужбою Проекту Закону України «Про основні засади діяльності органів державного фінансового контролю».

Прийняття Законопроекту прогнозувало змогу щодо розбудови цілісної, дієвої та ефективної системи державного фінансового контролю; створення ефективної інституційної основи для діяльності органів державного фінансового контролю; забезпечення концептуальних засад розвитку правової та методологічної бази функціонування державного фінансового контролю й діяльності органів державного фінансового контролю з наближенням до кращих практик Європейського Союзу у сфері аудиторської діяльності в державному секторі; сприяння зміцненню фінансово-бюджетної дисципліни; мінімізації зловживань у сфері державних фінансів; удосконалення управління та використання державних ресурсів державними органами й підвищення рівня їх усвідомлення відповідальності за результати діяльності.

Висновки. 3 вищенаведеного можна резюмувати, що всі перелічені нормативно-правові акти містять загальні положення щодо процесу проведення державного фінансового контролю, але вагоме значення має суворе встановлення єдиного затвердженого порядку, адже відсутність єдиного підходу до здійснення державного фінансового контролю $€$ негативним фактором, який спричиняє роз'єднаність, неузгодженість діяльності контрольних органів різних гілок влади на всіх рівнях, що позначається на результативності контролю, знижує його ефективність, уповільнює розвиток контрольної функції.

Як уже зазначалося, однією з визначальних умов повноцінної організації державного фінансового контролю $€$ наявність чіткої нормативної регламентації діяльності суб'єктів, уповноважених на виконання контрольних повноважень. 3 огляду на це, з метою унеможливлення плутанини під час планування, організації та здійснення заходів державного фінансового контролю, доцільно закріпити окремим розділом процесуальні особливості правового регулювання державного фінансового контролю в єдиному нормативно-правовому документі - у Законі України «Про основні засади здійснення державного фінансового контролю в Україні» від 26.01.1993, що сприятиме усуненню наявних прогалин вітчизняного законодавства.

Отже, на підставі аналізу чинного законодавства для вирішення вищезазначених проблем нормативно-правового регулювання державного фінансового контролю й удосконалення напрямів реформування державного фінансового контролю пропонується в Законі України «Про основні засади здійснення державного фінансового контролю в Україні» від 26.01.1993 закріпити такі положення:

1) державний фінансовий контроль - це регламентована спеціальними нормами права публічна діяльність, здійснювана органами публічного адміністрування, у тому числі спеціалізованими державними органами фінансового контролю, спрямована на забезпечення законності, раціональності, ефективності управління (формування, розподілу, використання, розпорядження) публічними фінансовими ресурсами з метою виявлення, усунення фінансових правопорушень у найбільш дієвий спосіб і та запобігання їм;

2) предмет державного фінансового контролю - це визначені нормами спеціального законодавства публічні фінанси (фінансові вартісні показники щодо діяльності об'єктів), які підлягають контролю в частині формування, володіння, використання та відчуження публічних фінансових ресурсів;

3) об'єкти державного фінансового контролю - це передбачена законодавством фактична публічна фінансова діяльність учасників (щодо яких здійснюються контрольні заходи суб'єктами державного фінансового контролю виконавчої влади всіх рівнів, підприємства, установи, організації) фінансових правовідносин;

4) суб'єкти державного фінансового контролю - це органи публічного адміністрування, у тому числі спеціалізовані державні органи фінансового контролю, органи місцевого самоврядування, підприємства, установи, організації, їх структурні підрозділи, які наділені контрольними повноваженнями, мають суб'єктивні права та виконують спеціальні юридичні обов'язки щодо управління (формування, розподілу, використання, розпорядження) публічними фінансовими ресурсами й несуть відповідальність установленими нормами права;

5) організація та здійснення державного фінансового контролю ґрунтується на універсальних принципах: верховенства права, законності, гласності, об'єктивності, незалежності, системності, ефективності та специфічних принципах прикладного характеру: моральні й етичні принципи, компетентність, професіоналізм, відповідальність, непідкупність суб'єктів контролю, узгодженість дій різних контролюючих органів;

6) єдині стандарти державного фінансового контролю містять основні вимоги до проведення окремого виду, форми чи методу державного фінансового контролю і затверджуються Кабінетом Міністрів України;

7) види державного фінансового контролю: зовнішній фінансовий контроль (аудит); внутрішній фінансовий контроль (аудит);

8) форми державного фінансового контролю: загальні (фінансовий аудит, аудит ефективності); спеціальні (аудит діяльності суб'єктів господарювання; аудит державних (регіональних) цільових програм; аудит виконання бюджетних програм; аудит місцевих бюджетів; аудит використання інформаційних технологій; аудит інвестиційних проектів, аудит Пенсійного фонду України, фондів загальнообов'язкового державного соціального страхування);

9) методи державного фінансового контролю: аудит, інспектування, ревізія, моніторинг закупівлі, перевірка закупівель;

10) повноваження й порядок діяльності органів державного фінансового контролю визначаються Конституцією України, цим та іншими законами України згідно з методами його проведення;

11) державний внутрішній фінансовий контроль - це система здійснення внутрішнього контролю, 
проведення внутрішнього аудиту, інспектування, провадження діяльності з їх гармонізації з метою забезпечення якісного управління ресурсами держави на основі принципів законності, економічності, ефективності, результативності й прозорості;

12) державний зовнішній фінансовий контроль - це контроль, що здійснюється визначеними нормативно-правовими актами незалежними конституційними органами в межах наданих їм повноважень;

13) заходи державного фінансового контролю: аудит, інспектування, моніторинг закупівель і перевірки закупівель здійснюється відповідно до Єдиного Порядку проведення органами державного фінансового контролю, встановленого Кабінетом Міністрів України.

Підсумовуючи вищевикладене, варто зазначити, що за умови реалізації запропонованих змін у спеціальне законодавство з питань державного фінансового контролю вони позитивно не лише впливатимуть на нормативно-правове регулювання діяльності органів державного фінансового контролю, а й сприятимуть створенню цілісної, ефективної системи державного фінансового контролю, зміцненню фінансово-бюджетної дисципліни, удосконаленню управління та використання державних ресурсів органами публічної адміністрації.

\section{Література}

1. Азаренкова Г.М. Шляхи удосконалення державного фінансового контролю в Україні: окреслення та обґрунтування. Бізнес Інформ. 2013. № 12. С. 280-283.

2. Жураковський Т.Б. Проблеми і стратегічні пріоритети розвитку системи державного фінансового контролю. Cттратегічні пріоритети. 2009. № 2 (11). С. 200-204.

3. Шевченко Н.І., Куліченко В.О. Державний фінансовий контроль в Україні: сучасний стан, проб лематика, напрямки реформування. Державне управління: удосконалення та розвиток. 2012. № 1. URL: http://nbuv.gov.ua/ UJRN/Duur_2012_1_3.

4. Пожар Т.О. Сучасний стан та проблеми фінансово-бюджетного механізму державного фінансового контролю в Україні. Вісник Східноєвропейського університету економіки і менеджменту. Серія «Економіка і менеджмент». 2012. № 1. С. 58-63.

5. Романів Є.М., Долбнєва Д.В. Необхідність та напрямки удосконалення системи державного фінансового контролю в Україні як вимога сьогодення. ScienceRise. 2016. № 2 (1). С. 35-38.

6. Організаційно-правовий механізм державного фінансового контролю в Україні / К.Є. Дубовик, В.Г. Гор- ник, В.В. Шпачук, С.О. Кравченко. Фінансово-кредитна діяльність: проблеми теорії та практики. 2019. Том 3. № 30. С. 340-350.

7. Есманов О.М. Реформування системи державного фінансового контролю в Україні. Бізнес Інформ. 2012. № 12. С. 32-34.

8. Голоядова Т.О. Правові аспекти функціонування державного фінансового контролю в Україні та необхідність удосконалення вітчизняного законодавства до законодавства ЄС. Південноукраїнський правничий часопис. 2015. № 1. С. 68-71.

9. Ровинський Ю.О. Модернізація системи правового забезпечення державного фінансового контролю України в контексті європейського. Правова держава. 2018. № 31. С. 53-60.

10. Молчанов Д.В. Удосконалення адміністративно-правового регулювання фінансового контролю та моніторингу як засобів протидії тінізації економіки України 3 урахуванням міжнародного досвіду. Підприємництво, господарство і право. № 10. 2017. С. 117-122.

11. Сюркало Б.І. Державний фінансовий контроль в контексті сталого економічного розвитку. Державне управління: удосконалення та розвиток. 2012. № 2. URL: http://nbuv.gov.ua/UJRN/Duur_2012_2_11.

12. Про основні засади здійснення державного фінансового контролю в Україні : Закон України від 26.01.1993 № 2939-XII. Відомості Верховної Ради України. 1993. № 13. Ст. 110.

13. Про основні засади діяльності органів державного фінансового контролю : Проект Закону України від 14.09.2018 № 9086. URL: http://w1.c1.rada.gov.ua/pls/ zweb2/webproc4_1?pf3511=64601.

14. Про схвалення Стратегї реформування системи управління державними фінансами на 2017-2020 роки : Розпорядження Кабінету Міністрів України від 08.02.2017 № 142-р. Офіційний вісник України. 2017. № 23. СТ. 659.

15. Про Стратегію сталого розвитку «Україна - 2020» : Указ Президента України від 12.01.2015 № 5. Офіційний вісник України. 2015. № 4. Ст. 67.

16. Про схвалення Концепції реалізації державної політики у сфері реформування системи державного фінансового контролю до 2020 року : Розпорядження Кабінету Міністрів України від 10.05.2018 № 310-р. Офіційний вісник України. 2018. № 41. Ст. 1458.

Прасюк В. М., здобувач кафедри адміністративного та господарського права Запорізького національного університету 